Journal of Social Sciences 7 (1): 33-41, 2011

ISSN 1549-3652

(C) 2010 Science Publications

\title{
Assessing the Environmental Attitude among Pupil Teachers in Relation To Responsible Environmental Behavior: A Leap towards Sustainable Development
}

\author{
Sudeshna Lahiri \\ Department of Education, University of Calcutta, Alipore Campus, \\ 1, Reformatory Street Kolkata, 700027; India
}

\begin{abstract}
Problem statement: Recognizing the importance of 'Environmental Education' to be introduced in every level of school education, agencies responsible for curriculum reforms and text books preparation in India have made the subject as an integral part. It is felt necessary to investigate whether the teachers, who are disseminating the knowledge, are equipped with environmental attitude and the behavior towards environment so that they may shape up the behavior of their students. Thus, the present study is pertinent to be conducted over trainee teachers perusing B.Ed course intended to hone the skills for future profession and desirable criteria to be a 'School Teacher' to ascertain relationship of Responsible Environmental Behavior (REB) with Environmental Attitude (EA) and Scientific Attitude (SA). Approach: Present study involves descriptive survey research with a sample of 300 pupil teachers from randomly selecting four Teachers' training institute affiliated to University of Calcutta, India. Data is subjected to descriptive statistics, t-test, F-test as well as coefficient of correlation over pre-service and in-service pupil teachers belonging to Science; Commerce and Humanities streams of studies. Results: The result shows low correlation between EA and REB of pupil teachers while there is a significant correlation between REB and SA. Similarly, there are significant differences for both EA and REB between in-service and pre-service teachers whereas a significant effect of courses of study on EA is reported with no significant effect on REB of pupil teachers. Conclusion: The study suggests redesigning activities involved in teachers' training courses and assessing the determinant attitudes which may lead to responsible behavior of pupil teachers towards the green earth. The curriculum for teacher training should focus on developing scientific attitude irrespective of stream of affiliation of prospective teachers along with opening a field of research, eco-psychology, for further research.
\end{abstract}

Key words: Responsible environmental behavior, environmental attitude, pupil teachers, teacher training institute, sustainable development, Responsible Environmental Behavior (REB), Environmental Attitude (EA), Scientific Attitude (SA)

\section{INTRODUCTION}

The relevance of including 'sustainable development' in B. Ed syllabus of teacher training institutes is that the National policy on education-1986 (India) and NCFSE (2000) highlight the need for including Environmental concerns at all the levels of schoolings. The Honorable Supreme Court of India has endorsed a model syllabus (2004) prepared by the NCERT for introducing environmental studies as a compulsory subject school. With all effort from agencies responsible for determining quality education, school teachers have the major duty to instill values and attitude among students through the subjects they are teaching in school so that students could behave sensibly towards the environment and contribute towards sustainable development. For this noble task, it is necessary that teacher training programme should be designed to equip trainee teachers for how to inculcate attitude through different subjects and this requires that pupil teachers should have positive attitude towards environment to manifest responsible environmental behavior. Hence, it is pertinent to assess the attitude of the students of teacher training programme and the relation with Environmental Responsible Behavior. Data is collected from 300 pupil teachers using instruments measuring Environmental attitude; scientific attitude and Responsible Environmental Behavior. Although, Responsible Environmental Behavior is not significantly related with Environmental attitude, however, it is significantly related with scientific attitude. Differences due to Teaching experiences and courses of study are significant on Environmental attitude. The teacher 
training programme also provides opportunities to be teacher educator offering Master of Education (i.e., M. Ed) and to pursue further research. Hence, the present study may open an avenue for research in 'ecopsychology' and curriculum reform for teacher training programme encouraging innovative pedagogical approach to be practiced in school.

The environmental threats in India ranges from- the degradation of rural land to the pollution, rapid urbanization with encroachment of forests, the accommodating fast growing population and congested cities. The plight is that the industrialization is the demand of the day where the nation has not yet arrived with a mechanism of conserving the environment and protecting it from the hazards caused due to constant effort of the country for modern amenities and making it 'livable' for civil society. As a result, the real costs of environmental degradation are mounting, when the forms of increasing health costs and mortality, reduced output in resource based sectors and irreversible loss of bio-diversity and overall environmental quality are considered (World Bank, 1993). Recognizing the necessity of knowledge regarding sustainability and the importance of healthier attachment between the 'Man' and the 'Nature', innumerable efforts have been made both on national and international level. In this regard, Higher education plays a major role of training future managers and professional in various sectors through research and multi-disciplinary approach. Besides Colleges and Universities, Higher education also includes teacher training institutes running teacher training programmes (i.e., B. Ed degree) which prepare prospective teachers for schools. The relevance of including 'sustainable development' in B. Ed syllabus is that the National policy on Education (1986) in India (renewed in 1992) has stated that Environmental consciousness should inform teaching in schools and colleges. This aspect will be integrated in the entire educational process. The National Curriculum Framework for School Education (NCFSE), 2000, also highlights the need for including Environmental concerns at all the levels of schoolings. On April 22, 2004, the Honorable Supreme Court of India has endorsed a model syllabus prepared by the National Council of Educational Research and Training (NCERT) for introducing environmental studies as a compulsory subject from class one to class twelve. With all this effort from Government of India and agencies responsible for determining quality education, school teachers have the major responsibility to instill values and attitude among students through the subjects they are teaching in school so that students could behave responsibly towards the environment and contribute towards sustainable development as several social scientists (Stapp, 1978; Tilbury , 1994; Wilson, 1994) have concluded that unless children develop a sense of respect and caring for the environment during their early years, they are at risk of never developing such attitudes later in life. The need of including environmental studies in school is realized as Tilbury (1994) indicates the importance of the early years "can prove to be critical for the environmental education of the child". Cohen (1984) documented that if children developed negative attitudes toward the environment during their early years, such attitudes are likely to become deeply entrenched. As pointed out by Chapman and Sharma (2001) on eco-school programme that school should be oriented towards two social objectives: (i) to foster the sense of responsibility for the state of the environment observed in all aspects of their personal and social Behavior and (ii) to teach them practical skills in how to monitor the environment, protect it, improve it and foster nature. From the conducted study, the majority of the Asian students appear to lack the environmental consciousness and attitude needed to protect their environment. However, objectives can only be achieved when their mentors actually believe in environment friendly Behaviors and practice them in daily life. It is necessary that teacher training programme should be designed to equip trainee teachers with the skills of instilling positive attitude towards environment through different subjects. This requires that pupil teachers themselves should have positive attitude towards environment to manifest responsibility towards environmental as social scientists have concluded that attitude has considerable influence on Behavior (Heberlein and Black, 1976; Weigel and Newman, 1976; Kallgren and Wood, 1989; Ramsey and Hungerford, 1989).

Reviewing the related literature, there is a scarcity of conducted study found in Indian context relating Environmental behavior with environmental attitude. The results shown by Abraham and Arjunan (2004) suggest that only a smaller proportion of the secondary school students possess high environmentally responsible behavior whereas no differential effect of gender and locale are noticed in their proenvironmental behavior. A low significantly positive correlation is found to exist between pro-environmental behavior and environmental knowledge in relation to gender. Larijani and Yeshodhara (2006) reveal that Iranian teachers had most favorable attitude in all the components except in Wildlife. The study conducted by Sengupta et al. (2009) find that sighted and visually impaired students belonging to secondary stage of education in West Bengal (India) do not differ with 
respect to pro-environmental behavior and gender. Most of the studies done earlier focused on environmental awareness. Cross-cultural studies have been not at all traced on environmental attitude among teachers. Results revealed by Shobeiri et al. (2006) that there are significant differences between Indian and Iranian primary school teachers in their level of environmental attitude. Also there are significant differences between them in environmental attitude across and within two groups with regard to their gender. Kumar and Patil (2007) reveal that students with environmental education background has better environmental attitude and find that there is no significant difference between male and female students in their attitude towards environmental pollution and related issues. There is also a dearth of studies in EuroAmerican Campuses and Asian countries. Results of the meta-analysis by Hines et al. (1987) indicate that the psycho-social variables of intention, locus of control, attitudes, personal responsibility and knowledge (in decreasing order of strength) are associated with Responsible Environmental Behavior. An investigation by Hungerford and Volk (1990) conclude that there are three categories of variables that contribute to responsible environmental behavior and hypothesis that these variables act in a complex and synergistic linear fashion: (1) entry level variable; (2) ownership variables and (3) empowerment variables. Numerous Projects demonstrate positive relationship between proenvironmental attitude and pro-environmental behavior (Abdul Wahab, 2008; Bodur \& Sarigollu, 2005; Fraj and Martinez, 2006; Meinhold and Mulkas, 2005; Cottrell, 2003; Gatersleben et al., 2002; Kaiser et al., 1999; Vogel, 1996; Lyons and Breakwell, 1994; Oskamp, 1991). Studies concerning demographic variables (gender, age, ethnic groups, educational background) in relation to environmental attitude, proenvironmental behavior, awareness and knowledge have also been carried out by many researchers (Milfont et al., 2006; Meinhold and Malkus, 2005; Eisler et al., 2003; Haikonen and Kiljunen, 2003; Hayes, 2001; Tikka et al., 2000; Uyeki and Holland, 2000; Zelezny et al., 2000; Lyons and Breakwell, 1994).

Review of literature aptly suggests that there is a lack of sufficient deep probe researches which could assess relationship between responsible environmental behavior and environmental as well as Scientific attitude taking in account of 'Pupil Teachers'. Further, it is worth investigating how subjects of teaching taken under different courses of study, i.e., Science, Humanities and Commerce, affects the environmental attitude of pupil teachers, thereafter, responsible environmental behavior. The results obtained could help to reconstruct the method of teaching to shape up responsible behavior among students. Hence, it is pertinent to assess the attitude of the students of teacher training programme, Bachelor of Education (i.e., B.Ed) and its relation with environmental responsible behavior.

\section{Objectives:}

- To find out the status of environmental attitude among pupil teachers

- $\quad$ To find out the status of responsible Environmental behavior among pupil teachers

- To find out the relationship between environmental attitude and responsible environmental behavior of pupil teachers

- To investigate the environmental attitude of pupil teachers in relation to teaching experience

- To investigate the responsible environmental behavior of pupil teachers in relation to teaching experience

- To find out the effect of courses of study on environmental attitude of pupil teachers

- To examine the effect of courses of study on responsible environmental behavior of pupil teachers

- To find out the relation between environmental attitude and responsible environmental behavior of pupil teachers when courses of study partial outs

- To find out the relation between responsible environmental behavior and scientific attitude of pupil teachers

\section{MATERIALS AND METHODS}

Population: Population of the study is defined as the students pursuing B. Ed degree from University of Calcutta, referred as 'Pupil Teachers'.

Sample: The Sample consists of 300 pupil teachers selected from randomly pooled four Teacher Training Colleges affiliated from University of Calcutta (India).

Tools: The tools, employed for the study, has been developed and adapted are.

Responsible Environmental Behavior (REB) scale: The scale is developed by researcher (2008) for Indian academia with reliability of 0.7905 analyzed by using Cronbach Alpha. It contains 35 items responded over 5point scale ranging as (a) daily; (b) Once in a week; (c) Once in a month; (d) Once in a year; (d) Never.

Scientific Attitude scale: The scale is adapted and modified in Indian context from the revised version of 
'The Scientific Attitude Inventory II (SAI)' by Moore and Foy (1997) to be responded over 5- point scale ranging from (a) strongly agree to (b) strongly disagree, for the thirty items. The internal consistency reliability for thirty items was established through Cronbach's alpha which is 0.927 .

Environmental Attitude scale: The scale consists of 35 statements capturing the pupil teachers' concern about environment responded over 5-point Likert Scale ranging from Strongly Disagree to Strongly Agree. The items are taken from the scale used by Tantawi et al. (2007) which are modified and adapted for Indian set up. The content validity of the scale has been established through consultation with experts.

Procedure: From randomly selected four Teacher Training Colleges affiliated to University of Calcutta (India), the tools are administered over 200 students of B.Ed course who are experienced teachers in deputation from respective schools and 100 students who have no teaching experience. The sample can further be divided on their respective courses of study where students from Humanities are 188; Commerce 31 and Science 81 among them 89 students are graduated in their respective streams and 211 students are with PostGraduate degree. The tools have been administered during practice of teaching in schools as school life experiences. For analysis of data, Pearson correlation coefficient (r) is computed to find out the relationship, t-test is used for the investigation of differences and Ftest for analyzing the affect of independent variables with appropriate descriptive statistics.

\section{RESULTS}

Measurement of eco-psychological construct starts with the inquiry that whether "environment" is only about pollution and natural world? Thus, the operational definition about the environmental attitude is all attitudes except those beliefs about self could be correctly called environmental attitudes where environment is any object exists outside of self. Similarly, the weighing of Responsible Environmental Behavior (REB) is the measurement of responsible manifestation towards the environment. Data has been analyzed by breaking its complexities in to simpler parts and putting them together for verification of the formulated hypotheses.

For the assessment of the status of Environmental Attitude (EA) of Pupil Teachers, the frequency distribution of data computed (Table 1) which is collected from Environmental Attitude Scale (EAS) after summing up the scores ranges from 35-175.
Table 1: Summary status of Environmental Attitude (EA) of pupil teachers

\begin{tabular}{llcc}
\hline Score d distribution & Levels & Frequency & Percent $(\%)$ \\
\hline $0-35$ & Very low & 0 & 0.00 \\
$35-70$ & Low & 4 & 1.33 \\
$70-105$ & Neutral & 21 & 7.00 \\
$105-140$ & High & 93 & 31.00 \\
$140-175$ & Very high & 182 & 60.67 \\
\hline
\end{tabular}

Table 2: Summary status of Responsible Environmental Behavior (REB) of pupil teachers

\begin{tabular}{llcc}
\hline Score distribution & Levels & Frequency & Percent $(\%)$ \\
\hline $0-5$ & Very low & 1 & 0.33 \\
$35-70$ & Low & 6 & 2.00 \\
$70-105$ & Neutral & 104 & 34.67 \\
$105-140$ & High & 184 & 61.33 \\
$140-175$ & Very high & 5 & 1.66 \\
\hline
\end{tabular}

The status of EA of pupil teachers is interpreted in Table 1 where it is evident that no pupil teacher has very low Environmental attitude and majority of the pupil teachers in teacher training colleges have shown very high Environmental attitude.

To know the status REB of Pupil Teachers, REB scale is used where highest score could be 175 and 35 is the lowest score. Distribution of scores with their level of interpretation is given in Table 2 which shows rarity of pupil teachers displaying very low REB.

The majority of pupil teachers have displayed high REB which is in the range of scores 105-140 (Table 2).

The data collected from 300 pupil teachers as subjected to statistical analysis gives correlation coefficient (Pearson's Product Moment Correlation) between Environmental attitude and REB as shown in Table 3a.

The average Environmental attitude (Table 3a) is 143 , which is indeed very high and average REB which is 109 . The correlation coefficient ( $r$ ) thus computed is not found significant at 0.05 level.

Data is further analyzed to probe more about Environmental Attitude and REB with respect to teaching experience of pupil teachers. The result is summarized in Table $3 \mathrm{~b}$ for Environmental attitude.

As Table $3 \mathrm{~b}$ shows, In-service Pupil teachers have higher mean environmental attitude score than those pupil teachers who are inexperienced. The difference in mean score is found to be significant at 0.05 levels.

Further, REB could be investigated in relation to teaching experience and analyzed data is summarized in Table 3c.

There is a difference in average score of Responsible Environmental Behavior of pupil teachers (Table 3c) in relation to their teaching experience. It is found that in-service pupil teachers have shown significantly higher Responsible Environmental Behavior than pre-service pupil teachers who are inexperienced. 
Table 3a:Summary of relation between environmental attitude and responsible environmental behavior of pupil teachers

\begin{tabular}{llllll}
\hline Variables & $\mathrm{N}$ & Mean & $\mathrm{SD}$ & $\mathrm{r}$-value & Significance \\
\hline $\begin{array}{l}\text { Environmental } \\
\text { attitude }\end{array}$ & 300 & 143.00 & 11.45 & 0.1013 & 0.204 \\
$\begin{array}{l}\text { Responsible } \\
\text { environmental } \\
\text { behavior }\end{array}$ & 300 & 109.39 & 12.57 & & \\
\hline *: Significant at 0.05 level & & & & & \\
\end{tabular}

Table 3b: Summary of Environmental Attitude (EA) of pupil teachers in relation to teaching experience

\begin{tabular}{lllllll}
\hline $\begin{array}{l}\text { Teaching } \\
\text { experience }\end{array}$ & $\mathrm{N}$ & $\begin{array}{l}\text { Mean } \\
\text { environmental } \\
\text { attitude }\end{array}$ & SD & SE & t-value & Significance \\
\hline $\begin{array}{l}\text { In-service pupil } \\
\text { teachers }\end{array}$ & 199 & 144.38 & 8.27 & 0.59 & & \\
$\begin{array}{l}\text { Pre-service pupil } \\
\text { teachers }\end{array}$ & 101 & 140.29 & 15.84 & 1.58 & $2.42^{*}$ & 0.046 \\
\hline *. Significant at 0.05 level & & & & & \\
\hline
\end{tabular}

*: Significant at 0.05 level

Table 3c: Summary of Responsible Environmental Behavior (REB) of pupil teachers in relation to teaching experience

\begin{tabular}{|c|c|c|c|c|c|c|}
\hline Teaching experience & $\mathrm{N}$ & $\begin{array}{l}\text { Mean } \\
\text { responsible } \\
\text { environmental } \\
\text { behavior }\end{array}$ & SD & SE & $\mathrm{t}$-value & Significance \\
\hline $\begin{array}{l}\text { In-service pupil } \\
\text { teachers }\end{array}$ & 199 & 113.17 & 13.00 & 0.92 & $2.62^{*}$ & 0.0423 \\
\hline $\begin{array}{l}\text { Pre-service pupil } \\
\text { teachers }\end{array}$ & 101 & 105.92 & 11.60 & 1.16 & & \\
\hline
\end{tabular}

*: Significant at 0.05 level

Table 4a: Summary of effect of courses of study on environmental attitude

\begin{tabular}{lllrll}
\hline Courses of study & $\mathrm{N}$ & Mean & \multicolumn{1}{c}{ SD } & F-value & Significance \\
\hline Humanities & 174 & 142.53 & 13.19 & $3.18^{*}$ & 0.041 \\
Commerce & 32 & 141.75 & 3.77 & & \\
Science & 94 & 149.55 & 7.52 & & \\
\hline
\end{tabular}

*: Significant at 0.05 level

Table 4b: Results of student-newman-keuls test for difference in mean ratings

\begin{tabular}{lll}
\hline Courses of study & Subset for alpha $=0.05$ & \\
\hline Humanities & 142.53 & 149.55 \\
Commerce science & 141.75 & \\
\hline
\end{tabular}

To find out the effect of courses of study on Environmental Attitude, data collected are subjected to F-test as shown in Table 4a.

It is evident from Table 4a that effect of courses of study is significant at 0.05 levels on environmental attitude. Comparing the means of courses of study, i.e., Humanities, Commerce and Science, it is found that mean score of pupil teachers belonging to Science stream is highest among the pupil teachers belonging to other streams. For further clarity, Student NewmanKeul test (Table 4b) is conducted to find out the significant difference amongst the Environmental attitude of pupil teachers belonging to different courses of study.
Table 5: Summary of effect of courses of study on responsible environmental behavior

\begin{tabular}{llllll}
\hline Courses of study & $\mathrm{N}$ & Mean & SD & F-value & Significance \\
\hline Humanities & 174 & 109.59 & 11.54 & 0.927 & 0.401 \\
Commerce & 32 & 101.25 & 13.52 & & \\
Science & 94 & 110.55 & 14.69 & & \\
\hline *: Significant at 0.05 level & & & &
\end{tabular}

*: Significant at 0.05 level

Table 6: Summary table of relation between environmental attitude and responsible environmental behavior of pupil teachers when controlled for courses of study

\begin{tabular}{llllll}
\hline Variables & Course & $\mathrm{N}$ & Mean & r-value & Significance \\
\hline Environmental & Humanities & 174 & 142.53 & 0.1013 & 0.404 \\
attitude & Commerce & 32 & 141.75 & & \\
& Science & 94 & 149.55 & & \\
Responsible & Humanities & 174 & 109.59 & & \\
environmental & Commerce & 32 & 101.25 & & \\
behavior & Science & 94 & 110.55 & & \\
\hline
\end{tabular}

*: Significant at 0.05 level

The Student Newman-Keul test conducted reveals that the Environmental attitude of pupil teachers belonging to Science teachers is significantly different from those belong to Commerce and Humanities stream. The effect of courses of study, i.e., Humanities, Commerce and Science, on Responsible Environmental Behavior is assessed using F-test given in Table 5.

The mean scores of the pupil teachers belonging to science is nearly same with those belonging to humanities. The mean score of pupil teachers from Commerce stream is appreciably low, but not significantly different from any of the mean scores from Science and Humanities.

As there is a significant effect of courses of study on Environmental attitude, the data are further subjected to partial correlation to find out the relationship between Environmental attitude and Responsible Environmental Behavior of pupil teachers when controlled for courses of study.

It is evident from Table 6 that there is no significant relation between Environmental attitude and Responsible Environmental Behavior when courses of study are controlled for when data is subjected to partial correlation.

As the mean score for Responsible Environmental Behavior for the pupil teachers belonging to science stream is nearly equal to those belonging to Humanities as revealed in Table 5, it is pertinent to investigate upon the relationship of scientific attitude among pupil teachers in spite of respective streams with REB. To analyze the scientific attitude among Pupil Teachers, Scientific Attitude Scale has been employed. The data thus obtained is subjected to Pearson Product-Moment Correlation (r) as the result is given in Table 7. 
Table 7: Summary table for correlation between responsible environmental behavior and scientific attitude

\begin{tabular}{llll}
\hline Variables & N & Means & r-value \\
\hline Responsible environmental behavior & 300 & 109.390 & $* 0.310$ \\
Scientific attitude & & 112.628 & \\
\hline
\end{tabular}

*: Significant at 0.05 level

It is evident (Table 7) that there is a significant correlation between Responsible Environmental Correlation and Scientific Attitude when the scientific attitude scale is administered over pupil teachers without taking account of courses of study and affiliation of disciplines.

\section{DISCUSSION}

The United Nations Commission on Sustainable Development study program (1998) on Education for Sustainable Development called for United Nations Educational, Scientific and Cultural Organization (UNESCO) to develop guidelines for reorienting teacher training to address sustainability to change curriculums, programs, practices and policies to address sustainability in locally relevant and culturally appropriate ways. The teacher educators need to provide feedback to pre-service pupil teachers about the schools' reality to produce good prospective teachers and facilitate in-service pupil teachers with consultancy to develop as better professionals. Thus, it is needed that teacher-education programmes should be designed to equip the pupil teachers with techniques and strategies so that they can inculcate right attitude among students towards the environment and instill civic sense. Analyzing the results obtained from present study, it recommends aptly the reorientation, restructuring and modification of course material and curriculum of teacher education program for better environmental attitude of pupil teachers and behaves responsibly towards the environment.

The term 'pupil teacher' is used for prospective teachers aspire to be enter in the profession after the completion of B.Ed degree. The teacher training course, i.e., B.Ed, is segmented in to two parts: theory and practice teaching. The part 'practice teaching' gives school life experiences to the pupil teachers. This is the period when pupil teachers have already finished some portion of theoretical part of the syllabus and practicing the techniques taught to them during their course study. The status of Environmental Attitude of pupil teachers reveals in Table 1 that most of the pupil teachers (60.67\%) have a high Environmental Attitude. This shows their positive attitude towards environment to keep it clean, recycle and reuse the products. Similarly, it is evident from Table 2 that very few pupil teachers represent extreme sides of REB scale and indeed portray skewed populations of responsible environmental behavior. It may be suggested that to imbibe positive attitude and promote responsible environmental behavior among pupil teachers, more extra-curricular activities through organizing workshops, shows, movies and formation of environmental clubs should take place. This could be supported by Dushane (1974) who indicates that the manner in which ecological material is presented is very important towards environmental attitude change of learner.

The teacher-training institution could play a major role in propagating sustainability through educating new teachers, updating the knowledge and skills of inservice teachers, create teacher-education curriculum and provide professional development for practicing teachers. The low correlation coefficient $(r=0.1013)$, in Table 3 reveals that high positive environmental attitude may not lead to high responsible environmental behavior among pupil teachers. They may have concern and positive thinking for preserving and conserving the environment but may not carefully act to prevent hazards and to use environmental friendly products. In a recent survey of community attitudes to the environment, over $98 \%$ of the people of Hong Kong agreed that 'individuals have a responsibility to protect the environment' (Chan, 1996). However, when they were asked whether they had actually practiced environmental protection behaviors, citing examples such as refusal to use plastic bags or separating waste study for recycling, the percentage of positive responses dropped to between 30 and $60 \%$ respectively (Chan, 1996). The results indicated that there is a significant discrepancy between people's attitude and their actual behavior. Because of broad influence in curriculum design and implementation, as well as policy setting within educational institutions, faculty members of teacher-education institutions are perfectly poised to promote education for sustainable development (ESD) as Kellner and Waupinski (1974) concluded that "attitudes and values take time to nurture; environmental literacy is not short course". By working with the administrations and faculties of teacher education institutions, governments can bring about systematic, economically effective change (Hopkins, McKeown and International Network, 2005) which could reorient the behavior of pupil teachers and shape up future generation.

To know more about environmental attitude among pupil teachers, Table $3 \mathrm{~b}$ shows the results on the basis of experience of the teachers. The pupil teachers with teaching experiences have significantly shown more 
environmental attitude than who do not have any experience. It may be by virtue of the profession; inservice teachers are more concerned and consider their duty towards nature as well as betterment of their students. Although, Table 3a shows no significant correlation between environmental attitude and responsible environmental behavior, it is found (Table $3 b)$ that there is significant difference between inservice and pre-service teachers in relation to responsible environmental behavior. This may be due to that in-service pupil teachers have consciously modeled the favorable behavior towards nature while creating environmental awareness among the students. Individuals who display attitudes towards the environment that recognize the importance of nature and the environment, valuing it for its own sake, tend to display higher levels of self-reported or observed pro-environmental behavior than those with anthropocentric environmental attitudes (CoralVerdugo, 2002; Schultz, 2000; Stern et al., 1995).

For the investigation of effect of courses of study among the pupil teachers, it is revealed (Table 4a) that there is significant effect in relation to environmental attitude. For further clarification, Student NewmanKeul test (Table $4 \mathrm{~b}$ ) is employed which aptly suggests that pupil teachers with science as affiliation show significantly highest environmental attitude (149.55) among three streams, i.e., Humanities, Commerce and Science. Further, effect of courses of study has been also investigated in relation to responsible environmental behavior (as shown in Table 5) and found no significant effect of courses of study, i.e., Humanities, Commerce and Science. Interestingly, pupil teachers with commerce stream show low average REB score (101.25) in compared to those who belong to Humanities and Science. The differential behavior of pupil teachers belonging to Commerce stream may be due the more merchandised approach where environmental friendly products seem to be expensive.

The correlation between environmental attitude and responsible environmental behavior is further studied keeping effect of courses of study in control and found no significant correlation between environmental attitude and responsible environmental behavior even when the courses of study are controlled for. It is evident from Table 6 that the pupil teachers affiliated to science stream show highest environmental attitude which is significantly different (as given in Table 4b) from those who belong to Humanities and Commerce. It is pointed out in Table 7 that there is a significant correlation between scientific attitude and responsible environmental behavior of pupil teachers. It gives a clear explanation that it is logical thinking and rationality which is the factor of 'Scientific Attitude' help pupil teachers to act responsibly and reasonably. The positive correlation between scientific attitude and responsible environmental behavior complements and supports the findings which argue that the values affect environmental attitude as well as pro-environmental behavior (Schultz et al., 2005; Poortinga et al., 2004; Garling et al., 2003).

It is education sector which could play a major role in creating awareness among the citizens of the nation as the teachers of primary and secondary levels will play a key role in advancing education for sustainable development. Homburg and Stolberg (2006) propose that environmental stressors, mediated via appraisal processes (demand and resource appraisal), can activate problem-focused coping, which in turn leads to proenvironmental behavior (Gardner and Stern, 1996). Teachers are privileged to educate future leaders, professionals, laborers, parents and citizens of the world. Although the efforts of teachers are often ignored in our modern society, they are the only hope for creating civil and sustainable societies. Furthermore, teacher-education institutions hold the key to equipping teachers to address sustainability in their classrooms and thus shape the future of communities and nations around the world (McKeown, et.al, 2002). To conclude, it is the demand of the day that teacher training institutes should take the responsibility to prepare teachers for creating awareness among architects of the nation to behave conscientiously towards our 'nature'.

\section{CONCLUSION}

The major suggestions of the present study is that the curriculum of teacher-education programme should be reformed in India giving birth to inculcate values to protect and save our environment for tomorrow. The programme should stress upon developing scientific attitude among pupil teachers irrespective of their discipline. The community outreach programme should be organized and pupil teachers should be made to survey the rural regions where they can observe how people are thriving on 'nature' and to organize awareness programmes in villages, slums and industrial areas. The experiences of in-service pupil teachers should be shared and invited to train pre-service pupil teachers. Teaching strategies should be evolved through researches in the area of eco-psychology to bridge the gap between man and the nature. In sum, teacher training institutions should join hands with policy makers to arm prospective teachers with methods and strategies so that they can efficiently teach in schools how renewable and non-renewable resources could be 
used and protected to preserve, conserve and sustain for future generations.

\section{REFERENCES}

Abdul-Wahab, S.A., 2008. A preliminary investigation into environmental awareness of the Omani public and their willingness to protect the environment. Am. J. Environ. Sci., 4: 39-49. DOI 10.1007/s10584-009-9777

Abraham, M. and K.K. Arjunan, 2004. Proenvironmental behavior and environmental knowledge: A study among secondary school students. J. Ind. Educ., 30: 17-24.

Bodur, M. and E. Sarigollu, 2005. Environmental sensitivity in a developing country: Consumer classification and implications. Environ. Behav., 37: 487-510. DOI: 10.1177/0013916504269666

Chan, K.K.W., 1996. Environmental attitudes and behavior of Secondary school students in Hong Kong. Environmentalist, 16: 297-306. DOI: 10.1016/j.sbspro.2010.03.806

Chapman, D. and K. Sharma, 2001. Environmental attitudes and behavior of primary and secondary students in Asian cities: An overview strategy for implementing an eco-schools programme. Environmentalist, 21: 265- 272. DOI: 10.1023/A: 1012996016601

Cohen, M. J.1984. Prejudice against nature. Freeport, ME: Cobble-smith.

Coral- Verdugo, V. 2002. A structural model of proenvironmental competency. Environ. Behav., 34: 531-549. DOI: $10.1177 / 00116502034004008$

Cottrell, S.P., 2003. Influence of sociodemographic and environmental attitude on general responsible environmental behavior among recreational boaters. Environ. Behav., 35: 347-375. DOI: 10.1177/0013916503035003003

Dushane, J. 1974. In-service programs for teachers in North-West Ohio. J. Environ. Educ., 5: 12-14. DOI: 10.1080/00958964.1974.9941975

Eisler, A.D., H. Eisler and M. Yoshida, 2003. Perception of human ecology: Cross-cultural and gender comparisons. J. Envir. Psychol., 23: 89-101. DOI: 10.1016/S0272-4944(02)00083-X

Fraj, E. and Martinez, E., 2006. Environmental values and lifestyle as determining factors of ecological consumer behavior: An empirical analysis. J. Consumer Market., 23: 133-144. DOI: 10.1108/07363760610663295

Gardner, G.T. and Stern, P.C. 1996. Environmental Problems and Human Behavior. 1st Edn., Allyn and Bacon, Boston, ISBN: 0205156053, pp: 300.
Garling, T., S. Fujii, A. Gärling and C. Jakobsson, 2003. Effects of social values orientation on Moderating determinant pro environmental between intention. J. Environ. Psychol., 23: 1-9. DOI: 10.1016/S0272-4944(02)00081-6

Gatersleben, B., I. Steg and C. Vlek, 2002. Measurement and determinants of environmentally significant consumer behavior. Environ. Behav., 34: 335-362. DOI: 10.1177/0013916503251466

Hayes, B.C., 2001. Gender, scientific knowledge and attitudes toward the environment: A cross-national analysis. Politic. Res. Q., 54: 657-671. DOI: 10.1177/106591290105400309

Heberlein, T.A. and J.S. Black, 1976. Attitudinal specificity and the prediction of behavior of behavior in a field setting. J. Personality Soc. Psychol., 33: 474-479. DOI: 10.1037/00223514.33.4.474

Hines, J.M. et al. 1987. An analysis and synthesis of research on responsible environmental behavior. J. Environ. Educ., 18:1-8. ISSN: 00958964

Homburg, A. and A. Stolberg, 2006. Explaining proenvironmental behavior with a cognitive theory of stress. J. Environ. Psychol., 26: 1-14. DOI:10.1016/j.jenvp.2006.03.003

Hopkins, Charles, McKeown, Rosalyn and the International Network, 2005. Guidelines and recommendation for reorienting teacher education to address sustainability. Education for Sustainable Development in Action Technical Paper no. 2. Paris: UNESCO. ONLINE: http://unesdoc.unesco.org/images/0014/001433/14 3370E.pdf

Hungerfolk, L. and T. Volk, 1990. Changing learner behavior through environmental education. J. Environ. Educ., 21: 8-21. ISSN-0095-8964

Kaiser et al., 1999. Environmental attitude and ecological behavior. J. Environ. Psychol., 19: 1-19. https://home.zhaw.ch/ crb/dateien/KaiserWoelfing-Fuhrer99.pdf

Kallgren, C.A. and W. Wood, 1989. Access to attituderelevant information in memory as determinant of attitude-behavior consisting. J. Exp. Soc. Psychol., 22: 238-258.

Kellner, R. and R. Wanpinski, 1974. All about project I-C-E. J. Environ. Educ., 5: 27-28. DOI: 10.1080/00958964.1974.9941979

Kumar, K.S. and S.M. Patil, 2007. Influence of environmental education on environmental attitude of the Post-graduate students. Edutracks, Hyderabad, 6: 34-36. 
Homburg, A. and A. Stolberg, 2006. Explaining proenvironmental behavior with a cognitive theory of stress. J. Environ. Psychol., 26: 1-14. DOI:10.1016/j.jenvp.2006.03.003

Larijani, M. and K. Yeshodhara. 2006. Relationship between environmental attitude and environmental awareness among higher primary school teachers of India and Iran. J. All Ind. Associat. Educ. Res.18: 17-21.

Lyons, E. and G.M. Breakwell, 1994. Factors predicting environmental concern and indifference in 13-16Year-Olds. Environ. Behav., 26: 223-238. DOI: 10.1177/001391659402600205

McKeown, Rosalyn; Hopkins, Charles; Rizzi, Regina; \& Chrystalbridge, Marianne. 2002. Education for Sustainable Development Toolkit, version 2 . Knoxville: Waste Management Research and Education Institution. ONLINE http://www.esdtoolkit.org

Meinhold, J.L. and A.J. Malkus, 2005. Adolescent environmental behaviors: Can knowledge, attitudes and self-efficacy make a difference. Environ. Behav., 37: 511-532. DOI: 10.1177/0013916504269665

Milfont, T.L., J. Duckitt and L.D. Cameron, 2006. A cross-cultural study of environmental motive concerns and their implications for proenvironmental behavior. Environ. Behav., 38: 745767. DOI: $10.1177 / 0013916505285933$

Moore, R.W. and R.L.H. Foy, 1997. The Scientific Attitude Inventory: A Revision (SAI II). J. Res. Sci. Teach., 34: 327-336. DOI: 10.1002/(SICI)1098-2736(199704)34

Oskamp, S. et al., 1991. Factors influencing household recycling behavior. Environ. Behav., 23: 494-519.

Poortinga, et al. 2004. Values, environmental concern and environmental behavior: A study its household energy use. Environ. Behav., 36: 70-93. DOI: 10.1177/0013916503251466

Ramsey, J.E. and H.R. Hugerford, 1989. The effects of issue investigation and action training on environmental behaviors in Seventh grade students. J. Environ. Educ., 20: 29-34. DOI: $10.1080 / 00958964.1989 .9943036$

Schultz et al., 2005. Values and their relationship to environmental concern and conservation behavior. J. Cross-Cultural Psychol., 36: 457-475. DOI: 10.1177/0022022105275962

Sengupta, M., D. Banerjee and P. Maji, 2009. Effect of sight and gender on environmental awareness and pro-environmental behavior amongst school students. J. All Ind. Associat. Edu. Res., 21: 60-63. ONLINE:http://www.ejournal.aiaer.net/vol21109/9 .Sengupta,Banerji\%20\&\%20Maji.pdf
Shobeiri, S.M., B. Omidvar and N.N. Prahallada, 2006. Influences of gender and type of school on environmental attitude of teachers in Iran and India. Int. J. Environ. Sci. Technol., 3: 351-357. http://www.ceers.org/ijest/issues/full/v3/n4/304004 .pdf

Stapp, W., 1978. An instructional model for environmental education. Prospects, 8: 495-507.

Stern, P.C., T. Deitz and G.A. Guagnano, 1995. The new ecological paradigm in social- psychological context. Environ. Behav., 27: 723-743. DOI: 10.1177/0013916595276001

Tantawi, P. et al., 2007. Attitude towards the environment: An empirical investigation on Egyptian consumers. ONLINE cscanada.net/index.php/mse/article/view/1273/1348

Tarrant, M.A. and H.K. Cordell, 1997. The effect of respondent characteristics on general environmental attitude-behavior correspondence. Environ. Behav., 29: 618-637. DOI: $10.1177 / 0013916597295002$

Tikka et al., 2000. Effects of educational background on students' attitudes, activity levels and knowledge concerning the environment. J. Environ. $\quad$ Educ., 31: 12-19. DOI: 10.1080/00958960009598640

Tilbury, D., 1994. The Critical Learning Years for Environmental Education. In: Environmental Education. In: Environmental Education at the Early Childhood Level, Wilson, R.A. (Ed.). Washington, D.C. North American Association for Environmental Education, pp: 11-13.

Uyeki, U.S. and L.J. Holland, 2000. Diffusion of proenvironment attitudes. Am. Behav. Sci., 43: 646-662. DOI: 10.1177/00027640021955478

Vogel, S., 1996. Farmers' environmental attitudes and behavior. Environ. Behav., 28: 591-613. DOI: 10.1177/001391659602800502

Weigal, R.H. and L.S. Newman, 1976. Increasing attitude-behavior correspondence by broadening the scope of the behavior measure. J. Personality Soc. Psychol., 33: 793-802.

Wilson, R.A., 1994. Environmental Education at the Early Childhood Level. 1st Edn., North American Association for Environmental Education, Washington, DC., ISBN:1884008143, pp: 126.

World Bank. 1993. Toward an Environmental Strategy for Asia. In: Brandon, C. and Ramankutty, R. (Eds.). World Bank Publications, Washington, D.C., ISBN: 10: 0821327356, pp: 210.

Zelezny et al., 2000. New ways of thinking about environmentalism: Elaborating on gender differences in environmentalism. J. Soc. Issues, 56: 443-457. DOI: 10.1111/0022-4537.00177 